\title{
(Laws) Made in the 'First World': A TWAIL Critique of the Use of Domestic Legislation to Extraterritorially Regulate Global Value Chains
}

Caroline Omari Lichuma*

Georg-August Universität Göttingen, Göttingen, Germany

carollichuma@gmail.com; caroline.lichuma@stud.uni-goettingen.de

$\begin{array}{lr}\text { Abstract } & 497\end{array}$

$\begin{array}{ll}\text { Keywords } & 498\end{array}$

I. A Brief Introduction $\quad 498$

II. The Long Arm of the (National) Law: Global Value Chains and Their Extraterritorial Regulation Through Domestic Laws $\quad 501$

$\begin{array}{ll}\text { 1. Background } & 501\end{array}$

2. A Comparison of the Selected Domestic Supply Chain Laws 505

III. Through the Looking Glass: Using A TWAIL Lens to Scrutinise Domestic Supply Chain Laws

1. What's TWAIL Got to Do with It: Why a TWAIL Lens?

2. Some Concerns from a TWAIL Perspective

a) The Inadequacy of Unilateral Domestic Legislation in the Continuing Absence of Binding International Regulation

b) The Extraterritorial Application of Domestic Supply Chain Laws 518

c) “The (White) Saviour Complex" $\quad 522$

d) The Nature of the Companies' Duties Under Domestic Supply Chain Laws 524

e) The 'Burden' of the Burden of Proof $\quad 527$

f) The Paradox of Regulated Entities Becoming Regulators Themselves $\quad 528$

$\begin{array}{lr}\text { IV. Some Final Thoughts } & 531\end{array}$

\begin{abstract}
In the last ten or so years a 'new kid on the block' has arrived on the Business and Human Rights scene; that is, the use of domestic legislation to regulate the Global Value Chains (GVCs) of Transnational Corporations (TNCs). The intention behind these so called 'supply chain laws' is to (begin to) hold TNCs accountable for violations of human rights and environmental norms within the context of their operations. This need for national legislation can be partly attributed to the fact that the international level has been plagued with paralysis in attempting to come up with binding rules to regulate the behaviour of

\footnotetext{
* LLB, University of Nairobi; LLM, New York University; PhD Candidate, Georg-August
} Universität Göttingen.
\end{abstract}


TNCs. ${ }^{1}$ In fact, it is only as recently as August 2020 that the Second Revised Draft $^{2}$ of the binding treaty on TNCs and human rights has been completed and awaits next steps. ${ }^{3}$ Given this regulatory gap in the international legal sphere, the mushrooming of domestic supply chain laws in diverse countries such as the United States of America (USA), France and Germany (which on 11 June 2021 finally passed a corporate due diligence in supply chains law, the 'Lieferkettensorgfaltspflichtengesetz - LkSG') ${ }^{4}$ sets the stage for this paper's analysis of these laws in light of Third World Approaches to International Law (TWAIL), a critical scholarly network that offers a distinctive way of thinking about international law. "TWAIL scholarship has addressed multiple issues related to society, politics, identity, and economics - with an underlying commitment to democratic values and concerns in relations within and between the Third World and developed countries'6 and (as will be shown in subsequent sections of this article) can and should be extended to an analysis of domestic supply chain laws that are 'made in the First World'.

\section{Keywords}

Business and Human Rights - Third World Approaches to International Law (TWAIL) - Global Value Chains (GVCs) - Transnational Corporations (TNCs) - Germany

\section{A Brief Introduction}

GVCs divide and distribute the production process of commodities across countries, thus allowing multiple firms that form part of the product's 'value chain' to specialise in a specific task in the production process rather than

1 Phoebe Okowa, 'The Pitfalls of Unilateral Legislation in International Law: Lessons from Conflict Minerals Legislation', ICLQ 69 (2020), 685-717 (686).

2 OEIGWG Chairmanship, Legally Binding Instrument to Regulate, in International $\mathrm{Hu}-$ man Rights Law, The Activities of Transnational Corporations and Other Business Enterprises (2020) available online: <https://www.ohchr.org/>.

3 Surya Deva, 'The Business and Human Rights Treaty in 2020 - The Draft is "Negotiation Ready”, but are States Ready?' (September 2020), Opinio juris blog available online: <https:// opiniojuris.org/>.

4 Deutscher Bundestag, 'Beschlussempfehlung und Bericht des Ausschusses für Arbeit und Soziales (11. Ausschuss)', BT Drs. 19/30505 (9.6.2021) available online: <https://dserver.bundes tag.de/btd/19/305/1930505.pdf>.

5 James Gathii, 'TWAIL: A Brief History of its Origins, its Decentralized Network and a Tentative Bibliography', Trade Law and Development 3 (2011), 26-64, (26).

6 Gathii (n. 5), 27. 
having a single firm producing the entire product by itself. GVCs expanded in the $1990 \mathrm{~s}$ and $2000 \mathrm{~s}$ but that expansion has slowed down since the financial crisis of 2008. ${ }^{7}$ These value chains, whether intra-firm or inter-firm, regional or global in nature, shaped by TNCs account for $80 \%$ of global trade. ${ }^{8}$ Paradoxically however, despite the proliferation of GVCs there is a dearth of mandatory regulation of these players in both the domestic and the international sphere. This has led to 'inconsistent practice among firms, standards that are implemented in an ad hoc fashion, and weak incentives for changing behaviour' ${ }^{9}$

Questions thus arise as to who should (as a normative question) and actually does (as a descriptive matter) regulate GVCs, and how this regulation is done in today's globalised world. More specifically, in the absence of any sovereign with jurisdiction over the GVCs, or any system of law binding on the GVC as a whole and each of its constituent actors, how are norms of coordination and behaviour trans-nationalised through the chain'?10 This paper attempts an analysis of a number of existing (and I might add, largely ineffectual) attempts at the national level to come up with a regulatory framework for TNCs that hopes to minimise human rights and environmental abuses within their GVCs. Internationally, despite current progress made in the quest to come up with a binding treaty to regulate business and human rights, ${ }^{11}$ that in August 2020 culminated in the Second Revised Draft of a legally binding instrument to regulate the activities of TNCs, ${ }^{12}$ the most widely accepted and concerted international action to regulate GVCs within the broader context of business and human rights remains the United Nations (UN) Guiding Principles on Business and Human Rights. ${ }^{13}$ These Guiding Principles formulate human rights standards that companies should respect in their supply and value chains. Unsurprisingly however, by their very nature, the principles are not binding and instead are "seen as a "responsibility" rather than a "duty" [...] to

7 World Bank Group, 'Trading for Development in The Age of Global Value Chains' (2020), World Development Report, available online: <https://www.worldbank.org/>.

8 United Nations Conference on Trade and Development, 'Global Value Chains: Investment and Trade for Development' (2013) World Investment Report available online: <https:// unctad.org/>.

9 Galit A. Sarfaty, 'Shining Light on Global Supply Chains', Harv. Int'l L. J. 56 (2015), 419463 (420).

10 The IGLP Law and Global Production Working Group, 'The Role of Law in Global Value Chains: A Research Manifesto', London Review of International Law 4 (2016), 57-79 (75).

11 Human Rights Council, '26/9 Elaboration of an International Legally Binding Instrument on Transnational Corporations and Other Business Enterprises with Respect to Human Rights' (2014), A/HRC/RES/26/9, available online: <https://documents-dds-ny.un.org/>.

12 OEIGWG Chairmanship (n. 2).

13 United Nations, 'Guiding Principles on Business and Human Rights: Implementing the United Nations "Protect, Respect and Remedy” Framework' (2011), available online: <https:// www.ohchr.org/>. 
underline the fact that, as a result of the international legal doctrine that nonState actors, such as corporations, are not subjects of international law, there is currently no general legal requirement for corporate actors to observe human rights under international human rights law'. ${ }^{14}$

Within this context, the million-dollar business and human rights question is why has international law proven to be 'all bark and no bite' or, maybe even more accurately, 'no bark and no bite' in the regulation of TNCs? There are no easy (or even finite) answers to this question. Despite the irrefutable logic in strengthening the international regulation of GVCs, 'geopolitical realities may mean that progress on this front is likely to be very slow'. ${ }^{15}$ One pertinent observation proffered in this regard to explain the regulatory reticence at the international level is 'the past complicity of international law in facilitating the exploitation of natural resources as part of the imperial project'. ${ }^{16}$ Does international law's guilty past, that allowed and enabled foreign companies such as the infamous Imperial British East India Company ${ }^{17}$ (and many other such companies) to plunder the natural resources of colonised countries, colour its present hesitation in the area of regulation of TNCs? While this paper's scope is limited to an analysis of the use of unilaterally enacted domestic laws in the regulation of GVCs, it is worth observing that just like international law, such domestic supply chain laws also operate in the shadow of the legacy of the imperial project. Consequently, as will be further elaborated upon in section III below, when states elect to unilaterally legislate over GVCs by enacting laws that have extraterritorial effects, certain (TWAIL) tensions arise.

This paper posits that while the use of domestic laws to regulate GVCs has the potential to significantly shape corporate behaviour, national supply chain laws are only part of the solution and, in fact, can sometimes further the subjugation of Third World peoples both within the GVC itself and outside it. This is so especially because of the difficulties inherent in the extra territorial regulation of complex, multi-layered supply chains by the home state of the corporation in question without adequate involvement of the host state(s) and the (potentially) affected communities and peoples. The paper will proceed in three subsequent parts. Part II will analyse some specific examples of unilateral

14 Sarianna Lundan and Peter Muchlinski, 'Human Rights Due Diligence in Global Value Chains', in: Rob Van Tulder, Alain Verbeke and Liviu Voinea (eds.) New Policy Challenges for European Multinationals (Progress in International Business Research, Vol. 7), (Bingley: Emerald Group Publishing 2012), 181-201 (186).

15 Michael Rawling, 'Legislative Regulation of Global Value chains to Protect Workers: A Preliminary Assessment', The Economic and Labour Relations Review 26 (2015), 660-677 (673).

16 Okowa (n. 1), 686.

17 Kundan K. Thakur, 'British Colonial Exploitation of India and Globalization', Proceedings of the Indian History Congress 74 (2013), 405-415 (406). 
domestic regulation of GVCs. Recent attempts to introduce a supply chain legislation in Germany will form the foundation of the discussion here. A comparison will be made between the newly enacted German supply chain law and similar legislation in the USA and in France. The penultimate part III will thereafter utilise a Third World Approaches to International Law lens to critique these kinds of national supply chain legislations generally in order to illuminate some of the defects and deficiencies that could warrant concern from a third world vantage point. It will also offer some tentative recommendations for the drafting of domestic supply chain laws that are potentially capable of beginning to minimise these TWAIL concerns while maximising the protection of Third World peoples within the context of the operation of GVCs. The paper will finally end with a brief conclusion.

\section{The Long Arm of the (National) Law: Global Value Chains and Their Extraterritorial Regulation Through Domestic Laws}

\section{Background}

We are living in the age of GVCs. 'The time of single multinational corporations on their own creating, manufacturing, and selling a given product is long gone.'18 Today, GVCs are an inextricable part of most transnational corporate activity. The production processes of many TNCs are intimately tied to and significantly anchored in the activities of third-party suppliers abroad. Because of the need to 'circumvent the impasse at the multilateral level'19 and since many 'governments are now demanding more information on the origins of a company's products'20 there is an unprecedented increase in attempts to regulate TNCs and their GVCs through the use of supply chain laws at a domestic/national level (whether state or federal) and even at a regional/ supranational level in response to the 'growing awareness of the adverse social, environmental, economic, and other effects of global production'. ${ }^{21}$ Accordingly, it can be said that 'domestic supply chain-related regulation is an avenue by which home states can potentially set environmental and human rights

18 Kevin Sobel-Read, 'Global Value Chains: A Framework for Analysis', Transnational Legal Theory 5 (2014), 364-407 (371).

19 Okowa (n. 1), 686.

20 Sarfaty (n. 9), 420.

21 Jaako Salminen and Mikko Rajavuori, 'Transnational Sustainability Laws and the Regulation of Global Value Chains: Comparison and a Framework for Analysis', 26 Maastricht J. Eur. \& Comp. L. 5 (2019), 602-627 (605). 
related norms for third party suppliers and their host governments via multinational companies' ${ }^{22}$ Clearly, these laws affect more than just the TNCs they set out to regulate. They also serve as an alternative to international law for shaping the behaviour of host governments by placing pressure on these host governments in developing countries to pass legislation aimed at preventing the TNCs from shifting their GVCs to other regions. ${ }^{23}$ Domestic supply chain laws herald the shift in the international regulation of TNCs from the prevailing model of 'transnational new governance' that is largely dependent on voluntary standards by private actors and international institutions, toward the use of domestic law to regulate the GVCs of TNCs.

For the purposes of this discussion, the home state is the place where the TNC is headquartered or the country that enacts the supply chain legislation in question, while the host state is any state other than the home state in which the TNC operates, or which is a significant source of goods or services for a corporate group or its constituent companies, i. e. the host state hosts part of the GVC of the specific TNC. A brief caveat is necessary here, the determination of the home state of a TNC is not always as easy as may appear at first blush. 'The complex corporate structure of MNCs (Multinational Corporations) often makes the determination of their nationality difficult. ${ }^{24}$

The development of domestic supply chain laws is directly related to the increase in GVCs and their attendant accountability deficits thus far, with TNCs either wittingly or unwittingly contributing to violations of human rights and environmental abuses within the context of their global operations. This bourgeoning of domestic laws can be further linked to the development and adoption of the Guiding Principles on Business and Human Rights which implement the UN 'Protect, Respect and Remedy' framework credited to Prof. John Ruggie. ${ }^{25}$ Specifically, principle 2 anticipates that states will set out clearly the expectation that all business enterprises domiciled in their territory and/or jurisdiction will respect human rights throughout their whole operations. Principle 3 thereafter elucidates upon the duty of states to protect human rights and urges states to, inter alia, enforce laws that require business enterprises to respect human rights and to encourage business enterprises to com-

22 Sarfaty (n. 9), 420.

23 Sarfaty (n. 9), 420.

24 Antal Berkes, 'Extraterritorial Responsibility of the Home States for MNCs' Violations of Human Rights' in: Yannick Radi (ed.), Research Handbook on Human Rights and Investment (Cheltenham: Edward Elgar 2018), 304-343 (307).

25 United Nations Office of the High Commissioner of Human Rights, 'Guiding Principles on Business and Human Rights: Implementing the United Nations "Protect, Respect and Remedy" Framework: Report of the Special Representative of the Secretary-General [SRSG] on the Issue of Human Rights and Transnational Corporations and other Business Enterprises, John Ruggie' (2011), UN Doc A/HRC/17/31, available online: <https://www.ohchr.org/>. 
municate how they address their human rights impacts. The much-needed impetus for states to begin enacting domestic supply chain laws may thus be partly attributed to these widely accepted ${ }^{26}$ (albeit sometimes criticised ${ }^{27}$ ) Guiding Principles. It is important to note however, that this assertion in no way intends to belittle the great strides and contributions made by social movements that called for the regulation of businesses in the context of human rights for the decades before the Ruggie Guidelines were adopted. ${ }^{28}$

Some examples of domestic supply chain laws include, the Californian 2010 Transparency in Supply Chains Act; ${ }^{29}$ the United Kingdom (UK) Modern Slavery Act of 2015,30 and the Australian Modern Slavery Act of $2018^{31}$ both of which focus on human trafficking and exploitation in GVCs; the Dutch Wet zorgplicht kinderarbeid ('duty of care in relation to child labour') of May 2019 which deals with child labour in GVCs; ${ }^{32}$ the French 2017 loi relative au devoir de vigilance des sociétés mères et des entreprises donneuses d'ordre (law on a duty of care for parent and buyer companies; 'loi vigilance'), 33 ' which requires large companies to extensively map the impacts of their value chains on fundamental rights, human rights, and the environment'; ${ }^{34}$ and the EU Conflict Mineral Regulation passed in 2017, but which came into force in January $2021 .^{35}$ The latest country to adopt a domestic supply chain law is Germany, whose Parliament passed the Act on Corporate Due Diligence in Supply Chains on 11 June 2021. ${ }^{36}$ The law was enacted after having received 412 votes in favour, 159 against and 59 abstentions. ${ }^{37}$

26 Penelope Simmons, 'International Law's Invisible Hand and the Future of Corporate Accountability for Violations of Human Rights', Journal of Human Rights and the Environment 3 (2012), 5-43 (10).

27 Simmons (n. 26), 11.

28 Institute for Human Rights and Business, 'Building a Movement: Reflections on the History and Future of Business and Human Rights' (December 2019), available online: $<$ https://www. ihrb.org/>.

29 (US) California Transparency in Supply Chains Act of 2010 (SB 657), California Civil Code, $\$ 1714.43$.

30 (UK) Modern Slavery Act 2015 c. 30.

31 (AUS) Modern Slavery Act 2018, No. 153, 2018.

32 (NL) Wet Zorgplicht Kinderarbeid 2019.

33 (FR) Law No. 2017-399 of 27.3.2017 relating to the duty of vigilance of parent companies and ordering companies.

34 Salminen and Rajavuori (n. 21), 606.

35 Regulation 017/821/EU of the European Parliament and of the Council of 17.5.2017 laying down supply chain due diligence obligations for Union importers of tin, tantalum and tungsten, their ores, and gold originating from conflict-affected and high-risk areas, [2017] OJ L $130 / 1$.

36 Deutscher Bundestag (n. 4).

37 Deutscher Bundestag, 'Bundestag Verabschiedet das Lieferkettengesetz' (2021), available online: <https://www.bundestag.de/>. 
At first glance these domestic supply chain laws may appear different because they focus on separate thematic areas such as child labour, human trafficking, environmental protection or conflict minerals. However, these laws are united by the fact that they do not compel TNCs to stop operations anywhere along their supply chain where the possibility of violations (human rights and/or environmental) are present. Rather, these laws either impose transparency and disclosure requirements upon the covered companies, ${ }^{38}$ or compel the TNCs in question to exercise due diligence. ${ }^{39}$ Due diligence requires the covered corporations to ascertain whether their business activities abroad are undermining human rights and to put in place strategies to avoid or mitigate these risks within their GVCs. For instance, the Organization for Economic Cooperation and Development (OECD) Due Diligence Guidance for Responsible Supply Chains of Minerals from Conflict-Affected and High-Risk Areas recommends that companies should follow five steps when conducting due diligence. These are: the establishment of strong management systems, the identification and assessment of risk through supply chain mapping, the design and implementation of a strategy to respond to identified risks, the conduct of an independent audit of supply chain due diligence and annual reporting on supply chain due diligence. ${ }^{40}$ In some cases, due diligence may be accompanied by a requirement (whether mandatory or voluntary) to report to the home government on the measures undertaken by the TNC in this regard. As an example,

'the California Transparency in Supply Chains Act does not mandate that businesses implement new measures to ensure that their product supply chains are free from human trafficking and slavery. Instead, the law only requires that covered businesses make the required disclosures - even if they do little or nothing at all to safeguard their supply chains. Companies subject to the Act must therefore disclose particular information within each disclosure category, and the Act offers companies discretion in how to do so. ${ }^{41}$

38 Patrick J. Keenan, 'United States Law and Conflict Minerals' in: Isabel Feichtner, Markus Krajewski and Ricarda Roesch (eds.), Human Rights in the Extractive Industries: Transparency, Participation, Resistance (Berlin/Heidelberg: Springer 2019), 27-50 (32-36).

39 Eric De Brabendere and Marys Hazelzet, 'Corporate Responsibility and Human Rights: Navigating Between International, Domestic and Self-Regulation' in: Yannick Radi (ed.), Research Handbook on Human Rights and Investment (Cheltenham: Edward Elgar 2018), 221243 (238).

40 OECD, 'OECD Due Diligence Guidance for Responsible Supply Chains of Minerals from Conflict-Affected and High-Risk Areas' (2013), OECD Publishing available online: $<$ https://www.oecd.org/>.

41 Kamala D. Harris, Attorney General California Department of Justice, 'The California Transparency in Supply Chains Act: A Resource Guide' (2015), available online: <https:// oag.ca.gov/>. 
Despite the proliferation of domestic supply chain laws this paper will restrict its analysis to only four examples: the California Transparency in Supply Chains Act which was the first such law to be passed anywhere in the world, ${ }^{42}$ the Dodd-Frank Act Sec 1502 which is geographically limited and only applies to companies whose supply originates from Congo and/or its neighbours, the French Corporate Duty of Vigilance Law and the German Supply Chain Law. This choice is deliberate, in order to illuminate the differences between the earliest examples of domestic supply chain laws (The California Transparency in Supply Chain Act and the Dodd Frank Act which were both enacted in 2010) and the most recent examples (such as the French Corporate Duty of Vigilance Law which came into effect in 2017 and the German Law passed in 2021 but which will come into force in 2023).43 Additionally, the French Law was selected because of its similarity to the German Law - the material scope of both laws includes human rights as well as the environment (even though the German Act limits the environmental duties to only three conventions). The intention behind these choices is twofold: Firstly, to show that domestic supply chain laws are now more sophisticated than ever before, with the recent laws moving away from pure disclosure regimes as was the case with the California Transparency in Supply Chain Act to the more demanding regulatory regimes encompassed by due diligence laws such as the German Supply Chain Act and the French Corporate Duty of Vigilance Law. Secondly, to highlight the fact that, regardless of the nature of obligations provided for under the various types of domestic supply chain laws (whether disclosure or due diligence or anything in between), the reliance upon domestic supply chain laws to extraterritorially regulate the GVCs of TNCs nevertheless raises some lingering concerns.

\section{A Comparison of the Selected Domestic Supply Chain Laws}

Salminen and Rajavuori suggest seven variables that may be utilised in comparisons of domestic supply chain laws from different jurisdictions. ${ }^{44}$ These include: 1) The type of legislation used to classify a statute at the most general level. For instance, whether it is a criminal law, an ad hoc disclosure, or

\footnotetext{
42 Adam Chilton and Galit Sarfaty, 'The Limitations of Supply Chain Disclosure Regimes' Coase-Sander Working Paper Series in Law and Economics, No. 766 (2016), 1-54 (4).

43 Initiative Lieferkettengesetz, 'What the new Supply Chain Act Delivers and What it Doesn't' (2012), available online: <https://lieferkettengesetz.de/>.

44 Salminen and Rajavuori (n. 21), 613-614.
} 
other type of law; 2) The statute's material scope, which is used to outline the problem or sector a statute purports to regulate. This could be conflict minerals, modern slavery, human rights, environmental protection; 3) The statute's personal scope, which is used to determine the actors or regulated entities who have obligations under it, e.g. large companies, importers, small companies; 4) How the Statute defines the value chain, which is used to describe how a statute understands both the general, e.g. mineral supply chain or textile supply chain and legal structure of the value chain, e.g. the corporate group including subsidiaries, specific tiers of contractual suppliers; 5) The statutory duties assigned, which describes the concrete legal requirements under it, e.g. disclosure, a risk mitigation plan, due diligence requirements; 6) The statutory repercussions for breach of duty, which is used to illustrate the legal consequences (or the lack of such) for failing to fulfil the statutory obligations, e.g. criminal prosecution, injunctive relief, fines, exclusion from the award of public contracts; and 7) The wider significance of the duty under the statute on other forms of liability, which is used to describe the relationship between a statute and the broader national systems of liability, e.g. tort liability under torts such as negligence and any accompanying defences.

With these variables in mind I will now turn to each of the specific domestic supply chain laws in turn.

\section{The California Transparency in Supply Chains Act}

This particular Act is state-wide and not federal in nature, and requires large retailers and manufacturers operating in California to conspicuously disclose on their websites their 'efforts to eradicate slavery and human trafficking from (their) direct supply chain for tangible goods offered for sale'. ${ }^{45}$ If the retail seller or manufacturer does not have a website, consumers are to be provided with the written disclosures within 30 days of receipt by the company of a written request for such disclosures. The law applies to all companies doing business in California and which have annual worldwide gross receipts of 100 million US dollars and that identify themselves as a retailer or manufacturer on their California tax return.

These companies are expected to address to what extent, if any, they have engaged with five main themes in their disclosures: verification of product supply chains to evaluate and address risks of human trafficking and slavery, audits of suppliers to evaluate supplier compliance with company standards for trafficking and slavery in supply chains, certification that materials incorporated into the product comply with the laws regarding slavery and human trafficking of the host countries, internal accountability standards and proce-

45 California Civil Code, $\$ 1714.43$, sub-division (a)(1). 
dures for employees or contractors failing to meet company standards regarding slavery and trafficking, and training on human trafficking and slavery particularly with respect to mitigating risks within the supply chains of products. $^{46}$

Interestingly though, in case of violations by the covered companies the sole remedy available under this Act is an action for injunctive relief that can be brought only by the California Attorney General. Private individuals thus lack locus standi to bring claims under the California Transparency in Supply Chains Act. Additionally, it is conceivable that a company complies with the disclosure provisions of the Act even while failing to take any tangible measures in reality to abolish slavery and trafficking from its supply chain, e. g. by issuing a disclosure that simply acknowledges the company's inaction.

\section{The Dodd-Frank Act Sec 1502}

Even though supply chain laws 'generally understand value chains as global, some statutes limit their geographical scope'. ${ }^{47}$ A noteworthy example of such a geographically limited supply chain law is section 1502 of the American Dodd-Frank Act ${ }^{48}$ which was passed by the United States (U.S.) Congress in 2010. This so-called "conflicts minerals provision" requires U.S. publicly listed companies to check their supply chains for tin, tungsten, tantalum, and gold, if they might originate in Congo or its neighbours, take steps to address any risks they find and to report on their efforts every year to the U.S. Securities and Exchange Commission (SEC)'. ${ }^{49}$ By imposing upon the covered companies an obligation to disclose the source of their minerals the law aims to dissuade these companies from engaging in trade that supports violent conflicts in the Congo and neighbouring regions.

\section{The French Corporate Duty of Vigilance Law}

The aforementioned French law establishing a 'duty of vigilance' for large multinational firms carrying out all or part of their activity in France was adopted by the French National Assembly in February 2017.50 The law, however, came into force only on 28 March 2017 after the French Constitutional Council partially invalidated certain sections that would have imposed civil liabilities for companies which failed to develop the diligence plan

46 California Civil Code, $\mathbb{\$} 1714.43$, sub-division (c).

47 Salminen and Rajavuori (n. 21), 618.

48 (US)Dodd-Frank Wall Street Reform and Consumer Protection Act SEC 1502 (2010).

49 Global Witness, 'US Conflict Minerals Law: Section 1502 of U.S. Dodd Frank Act - The Landmark US Law Requiring Responsible Minerals Sourcing' (2017), available online: $<$ https://www.globalwitness.org/>.

50 (France) Law No. 2017-399 of 27.3.2017 (n. 33). 
required under the law. ${ }^{51}$ This law differs from the other supply chain laws because it imposes a mandatory obligation on the affected companies to actually implement a vigilance plan, rather than merely requiring companies to report on their efforts, if any, to identify and mitigate human rights related risks as is the case with the California Transparency in Supply Chains Act.

The French law applies to very large limited liability companies (sociétés anonymes) defined as 'any company which at the end of two consecutive financial years employs at least five thousand employees within the company and its direct and indirect subsidiaries, whose head office is located on French territory, or that has at least ten thousand employees in its service and in its direct or indirect subsidiaries, whose head office is located on French territory or abroad." 52 The covered companies are mandated to 'create and implement a vigilance plan aimed at identifying and preventing potential human rights violations - including those associated with subsidiaries and supply chain members'. ${ }^{33}$ This vigilance plan, which should be drafted in association with the company stakeholders, is expected to include 'a mapping that identifies, analyses, and ranks risks; procedures to regularly assess, in accordance with the risk mapping, the situation of subsidiaries, subcontractors or suppliers with whom the company maintains an established commercial relationship; appropriate action to mitigate risks or prevent serious violations; an alert mechanism that collects reporting of existing or actual risks, developed in working partnership with the trade union organisations representatives of the company concerned; a monitoring scheme to follow up on the measures implemented and assess their efficiency'. ${ }^{54}$

All this information must be publicised by the concerned companies as part of their annual reports. Where a company fails in its compliance obligations in a three-month period after receiving a formal notice to comply with the duties, any person with a legitimate interest can apply to the court in order to compel the company to comply. As already highlighted above, the legislation initially contained civil penalties of up to 10 million euros for covered companies that failed to comply with the requirements. However,

51 Décision no. 2017-750 DC du 23.3.2017 du Conseil Constitutionnel, available online: $<$ https://www.conseil-constitutionnel.fr/>; Jeremy Martinez, 'Due Diligence: The French Constitutional Council partially invalidates a law implementing a due diligence obligation to parent firms and main contractor companies (Law on due diligence obligation of parent firms and main contractor companies)', 23.3.2017, Concurrences No. 4-2017, Art. No. 85138, 185.

52 European Coalition of Corporate Justice, French Corporate Duty of Vigilance Law (English Translation) (2017), available online: <http://www.respect.international/french-corpo rate-duty-of-vigilance-law-english-translation/>.

53 Michael Congiu, Stefan Marculewicz, John Kloosterman, Stephan Swinkels, Aaron Saltzman, and Lavanga Wijekoon, 'Dutch and French Legislatures Introduce New Human Rights Due Diligence Reporting Requirements’ (2017), available online: <https://www.littler.com/>.

54 European Coalition of Corporate Justice (n. 52). 
these provisions on civil fines intended to sanction indeterminate obligations' were struck down by the French Constitutional Council on the ground of unconstitutionality. That said, it is still possible for individuals harmed by a company's failure to create and implement the vigilance plan to seek damages for negligence. Article 2 of the Law provides that 'the author of any failure to comply with the duties specified in Article L. 225-102-4 of this code shall be liable and obliged to compensate for the harm that due diligence would have permitted to avoid'. 55

\section{The German Supply Chain Sourcing Obligations Act ('Lieferkettensorg- faltspflichtengesetz, LkSG')}

Germany is the latest country to join the domestic supply chain legislation bandwagon. The discussions preceding the passing of the Act provoked fierce debate in business, academic, ${ }^{56}$ and political circles. ${ }^{57}$ The law seeks to 'improve the international human rights situation by establishing requirements for responsible supply chain management for certain companies', 58 even though some critics have pointed out that it 'was massively weakened by business associations in negotiations and thus falls short of international human rights standards'. ${ }^{59}$ As such, the law is a 'political compromise'. ${ }^{60}$ More specifically, Section 1 of the law details the covered companies: when the law first comes into effect in 2023 it will apply to companies that have a registered office or branch in Germany and that employ at least 3000 employees, then from 1 January 2024 the threshold shall be 1000 employees. ${ }^{61}$ The Act includes employees posted abroad for purposes of calculating whether the threshold has been reached.

It defines 'protected legal positions' as 'those arising from the conventions for the protection of human rights' as listed in items $1-11$ of the annex. ${ }^{62}$ An environment related risk is thereafter defined as a condition that gives rise to a reasonable likelihood of one of the identified environment related duties. ${ }^{63}$

55 European Coalition of Corporate Justice (n. 52).

56 Verfassungsblog, 'Debate: Lieferkettengesetz Made in Germany' (2020), available online: $<$ https://verfassungsblog.de/>.

57 Erika Solomon, 'German Proposals for Supply Chain Law Spark Fierce Debate' (2020), Financial Times, available online: <https://www.ft.com/>.

58 Deutscher Bundestag (n. 4), 2.

59 European Centre for Constitutional and Human Rights (ECCHR), 'German Parliament Passes Human Rights Due Diligence Law' (2021), available online: <https://www.ecchr.eu/>.

60 Initiative Lieferkettengesetz (n. 43), 2.

61 Lieferkettensorgfaltspflichtengesetz (LkSG) ('Supply Chain Sourcing Obligations Act'), available online: <https://dserver.bundestag.de/btd/19/305/1930505.pdf> and <https://dserver. bundestag.de/btd/19/286/1928649.pdf >, $\mathbb{~} 1$.

62 Lieferkettensorgfaltspflichtengesetz (n. 61), $\$ 2$ (1).

63 Lieferkettensorgfaltspflichtengesetz (n. 61), $\$ 2$ (3). 
The Act requires the covered companies to conduct appropriate human rights and environmental due diligence in their supply chains as outlined in section $3 .{ }^{64}$ However, the comprehensive due diligence obligations only relate to the covered company and its direct suppliers. For indirect suppliers such a requirement only arises if there are factual indications that suggest a violation of a human right or an environmental obligation ('substantiated knowledge' of a possible infringement). ${ }^{65} \mathrm{~A}$ covered company is expected to establish a risk management system, ${ }^{66}$ define its in-house responsibility, ${ }^{67}$ carry out regular risk analyses ${ }^{68}$ submit a policy statement, ${ }^{69}$ establish preventive measures within the company's own business unit ${ }^{70}$ and vis-à-vis direct suppliers. ${ }^{71}$ In addition, the covered companies must also establish an effective complaints mechanism for the workers of the company as well as its business partners. ${ }^{72}$ They must also implement due diligence with regards to the risks of indirect suppliers. ${ }^{73}$ The Act additionally imposes reporting and documenting obligations on the covered companies ${ }^{74}$ and mandates them to prepare an annual report ${ }^{75}$ documenting their efforts in complying with the outlined requirements and to publish that documentation on their websites free of charge for a period of 7 years.

The Act sets out a number of penalties and fines for non-compliance. These include exclusion from the award of public contracts with the German government for a reasonable period of up to three years. ${ }^{76}$ Such exclusion requires a legally established infringement with a fine of at least 175,000 euros. ${ }^{77}$ The Act also anticipates fines both for complicit individuals (ranging

64 Lieferkettensorgfaltspflichtengesetz (n. 61), $₫ 3$ Sorgfaltspflichten.

65 Lieferkettensorgfaltspflichtengesetz (n. 61), \$ 9.

66 Lieferkettensorgfaltspflichtengesetz (n. 61), $\mathbb{\$} 4$ (1) die Einrichtung eines Risikomanagements.

67 Lieferkettensorgfaltspflichtengesetz (n. 61), $\mathbb{} 4$ (3) die Festlegung einer betriebsinternen Zuständigkeit.

68 Lieferkettensorgfaltspflichtengesetz (n. 61), $\$ 5$ Risikoanalyse.

69 Lieferkettensorgfaltspflichtengesetz (n. 61), $\$ 6$ (2) die Verabschiedung einer Grundsatzerklärung.

70 Lieferkettensorgfaltspflichtengesetz (n. 61), $\mathbb{} 6$ (1 and 3) die Verankerung von Präventionsmaßnahmen im eigenen Geschäftsbereich.

71 Lieferkettensorgfaltspflichtengesetz (n. 61), $\$ 6$ (4) gegenüber unmittelbaren Zulieferern.

72 Lieferkettensorgfaltspflichtengesetz (n. 61), $\$ 8$ die Einrichtung eines Beschwerdeverfahrens.

73 Lieferkettensorgfaltspflichtengesetz (n. 61), $\mathbb{\$} 9$ die Umsetzung von Sorgfaltspflichten in Bezug auf Risiken bei mittelbaren Zulieferern.

74 ) Lieferkettensorgfaltspflichtengesetz (n. 61), $\$ 10$ (1) Dokumentation.

75 Lieferkettensorgfaltspflichtengesetz (n. 61), \$10 (2) Berichterstattung.

76 Lieferkettensorgfaltspflichtengesetz (n. 61), $\$ 22$ Ausschluss von der Vergabe öffentlicher Aufträge.

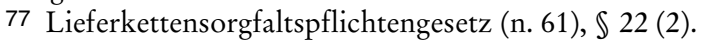


from 100,000 euros to 800,000 euros $)^{78}$ as well as for the company itself as a legal person or association of persons. ${ }^{79}$ In this latter case the fine will be computed as a percentage of the average annual turnover based on the significance of the administrative offense committed. ${ }^{80}$ It is noteworthy that the Act specifically provides that violations under it shall not give rise to civil liability, although any civil liability established independently of the Act remain unaffected. ${ }^{81}$

The domestic supply chain laws canvassed above can be comparatively evaluated as follows:

\begin{tabular}{|c|c|c|c|c|c|c|c|}
\hline $\begin{array}{l}\text { Supply } \\
\text { Chain Law }\end{array}$ & $\begin{array}{l}\text { Type of } \\
\text { Law }\end{array}$ & $\begin{array}{l}\text { Material } \\
\text { Scope }\end{array}$ & Personal Scope & $\begin{array}{l}\text { Value } \\
\text { Chain }\end{array}$ & \begin{tabular}{|l|} 
Statutory \\
Duties
\end{tabular} & $\begin{array}{l}\text { Consequences } \\
\text { of Breach }\end{array}$ & $\begin{array}{l}\text { Other } \\
\text { Liability }\end{array}$ \\
\hline $\begin{array}{l}\text { California } \\
\text { Transparen- } \\
\text { cy in Supply } \\
\text { Chain Act }\end{array}$ & $\begin{array}{l}\text { Ad hoc } \\
\text { disclo- } \\
\text { sures }\end{array}$ & \begin{tabular}{|l|} 
Slavery \\
Human \\
Trafficking
\end{tabular} & \begin{tabular}{|l|} 
Retailers and \\
manufacturers \\
doing business \\
in California \\
with global gross \\
receipts over \\
100 M USD
\end{tabular} & $\begin{array}{l}\text { Product } \\
\text { supply } \\
\text { chains }\end{array}$ & $\begin{array}{l}\text { Annual } \\
\text { disclosure }\end{array}$ & $\begin{array}{l}\text { AG can seek } \\
\text { injunctive re- } \\
\text { lief }\end{array}$ & $\begin{array}{l}\text { Other re- } \\
\text { medies } \\
\text { available }\end{array}$ \\
\hline $\begin{array}{l}\text { Dodd-Frank } \\
\text { Act Sec } 1502\end{array}$ & Securities & $\begin{array}{l}\text { Conflict } \\
\text { minerals }\end{array}$ & $\begin{array}{l}\text { Companies fil- } \\
\text { ing with the } \\
\text { SEC that use the } \\
\text { identified } \\
\text { minerals origi- } \\
\text { nating from } \\
\text { DRC and neigh- } \\
\text { bouring areas }\end{array}$ & $\begin{array}{l}\text { Mineral } \\
\text { supply } \\
\text { chain }\end{array}$ & $\begin{array}{l}\text { Annual } \\
\text { disclosure }\end{array}$ & $\begin{array}{l}\text { Liability for } \\
\text { false/fraudu- } \\
\text { lent reporting }\end{array}$ & $\begin{array}{l}\text { No other } \\
\text { liability }\end{array}$ \\
\hline $\begin{array}{l}\text { The French } \\
\text { Vigilance } \\
\text { Law }\end{array}$ & $\begin{array}{l}\text { Due Dili- } \\
\text { gence }\end{array}$ & $\begin{array}{l}\text { Human } \\
\text { Rights } \\
\text { Environ- } \\
\text { ment }\end{array}$ & $\begin{array}{l}\text { French compa- } \\
\text { nies with } 5000 \\
\text { employees in } \\
\text { France or } 10,000 \\
\text { in France plus } \\
\text { abroad }\end{array}$ & \begin{tabular}{|l|} 
Equity \\
based \\
and con- \\
tract \\
based \\
value \\
chain
\end{tabular} & $\begin{array}{l}\text { Manda- } \\
\text { tory vigi- } \\
\text { lance plan }\end{array}$ & $\begin{array}{l}\text { Injunctive re- } \\
\text { lief } \\
\text { Fines }\end{array}$ & $\begin{array}{l}\text { Liability } \\
\text { under Tort }\end{array}$ \\
\hline $\begin{array}{l}\text { The German } \\
\text { LkSG }\end{array}$ & $\begin{array}{l}\text { Due Dili- } \\
\text { gence }\end{array}$ & $\begin{array}{l}\text { Human } \\
\text { Rights } \\
\text { Environ- } \\
\text { ment }\end{array}$ & $\begin{array}{l}\text { From } 2023 \text { com- } \\
\text { panies with } \\
3000 \text { employees } \\
\text { or more with a } \\
\text { registered of- } \\
\text { fice/branch in } \\
\text { Germany and } \\
\text { from } 2024 \text { com- } \\
\text { panies with } \\
1000 \text { or more } \\
\text { employees }\end{array}$ & $\begin{array}{l}\text { covering } \\
\text { the en- } \\
\text { tire life } \\
\text { cycle of } \\
\text { a prod- } \\
\text { uct; or } \\
\text { of a ser- } \\
\text { vice }\end{array}$ & \begin{tabular}{|l|} 
Manda- \\
tory risk \\
analysis, \\
preventive \\
measures \\
and reme- \\
dies
\end{tabular} & $\begin{array}{l}\text { Fines } \\
\text { Exclusion } \\
\text { from public } \\
\text { contracts }\end{array}$ & $\begin{array}{l}\text { Violations } \\
\text { under the } \\
\text { Act shall } \\
\text { not give } \\
\text { rise to civil } \\
\text { liability }\end{array}$ \\
\hline
\end{tabular}

78 Lieferkettensorgfaltspflichtengesetz (n. 61), $\$ 24$ (2).

79 Lieferkettensorgfaltspflichtengesetz (n. 61), $\$ 24$ (3).

80 Lieferkettensorgfaltspflichtengesetz (n. 61), \$24 (4).

81 Lieferkettensorgfaltspflichtengesetz (n. 61), \3 (3). 


\section{Through the Looking Glass: Using A TWAIL Lens to Scrutinise Domestic Supply Chain Laws}

\section{What's TWAIL Got to Do with It: Why a TWAIL Lens?}

For a long time, it has been the case that 'the suffering of impoverished people is irrelevant to the ruling standards of the global capital, which must measure excellence of economic entrepreneurship by standards other than those provided by endless human rights normativity'. ${ }^{82}$ However, this seems to have changed in the last ten or so years with the unprecedented increase in domestic supply chain laws. Are domestic supply chain laws part of the much-needed winds of change necessary to centre the human rights of Third World peoples within the context of the GVCs of TNCs? For instance, in the parliamentary discussions accompanying the passing of the German Act it was stressed that 'the present Due Diligence Act serves to improve the international human rights situation by establishing requirements for responsible supply chain management for certain companies'. ${ }^{83}$ The Act specifically goes on to list some of the core international human rights instruments such as the International Covenant on Civil and Political Rights and its Optional Protocol, the International Covenant on Economic, Social and Cultural Rights, and the Convention No. 87 of the International Labour Organization concerning freedom of association and protection of the right to organise (to mention just a few).

While domestic supply chain laws are an important contribution to the pursuit to humanise GVCs by addressing 'the human rights impacts of business activity, and, in particular, the business activity in so-called Third World states', ${ }^{84} \mathrm{I}$ argue that these laws do not do enough to circumvent censure from a TWAIL perspective. There is a 'long history of using international law to facilitate business activity in Third World states' 85 in ways that benefit foreign powers at unacceptable costs to local communities and peoples. This history can be extended to the analysis of domestic supply chain laws because, despite the fact that these laws are not really international per se, they borrow heavily from international law rules and principles, and have transnational effects. TWAIL insists that issues of material distribution and imbalance of power affect the way in which international

82 Upendra Baxi, The Future of Human Rights (New Delhi: Oxford University Press India 2006), 252.

83 Deutscher Bundestag (n. 4), 2.

84 Simmons (n. 26), 9.

85 Simmons (n. 26), 19. 
legal concepts, categories, norms, and doctrines are produced and understood'. ${ }^{86}$ As such this paper cautions that when international legal concepts, categories, norms, and doctrines in the area of business and human rights are transformed into domestic legislation, all too often these domestic supply chain laws, despite their best intentions, inadvertently or otherwise reinforce already existing inequalities and power imbalances to the detriment of Third World states and peoples thus simultaneously empowering and disempowering them.

TWAIL scholarship is 'best viewed as a broad dialectic (or large umbrella) of opposition to the generally unequal, unfair, and unjust character of an international legal regime that all too often (but not always) helps subject the Third World to domination, subordination, and serious disadvantage. ${ }^{87}$ TWAIL scholars, or TWAILers, 'consider and critique the power relationships entrenched in the structure of international law from the perspective of Third World peoples and states'. ${ }^{88}$ While there is 'arguably no single theoretical approach that unites TWAIL scholars', ${ }^{89}$ TWAILers are nevertheless 'united in their broad opposition to the unjust global order', ${ }^{90}$ and 'such scholarship or political action will be concerned with justice or the fairness of norms, institutions, processes, and practices in the transnational arena. Its overriding purpose must be the elimination of an aspect of Third World powerlessness'. ${ }^{91}$

One prominent TWAIL scholar, Chimni, urges TWAILers to - inter alia research on ways of 'increasing the accountability of transnational corporations' ${ }^{92}$ For example, this could be done by, 'the imaginative use of domestic legal systems to expose the oppressive practices of TNCs'. ${ }^{93}$ I would, however, take this one step further and argue for a certain 'self-awareness' on the part of first world states that chose to enact these kinds of laws, as well as a mindfulness of the asymmetrical power dynamics that exist between the first

86 Luis Eslava and Sundhya Pahuja, 'Between Resistance and Reform: TWAIL and the Universality of International Law', Trade Law and Development 3 (2006), 103-130, (105).

87 Obiora Okafor, 'Newness, Imperialism and International Legal Reform in Our Time: A TWAIL Perspective’, Osgoode Hall L. J. 43 (2005), 171-191, (176).

88 Simmons (n. 26), 19.

89 Luis Eslava and Sundhya Pahuja, 'Beyond the (Post)Colonial: TWAIL and the Everyday Life of International Law', Verfassung und Recht in Übersee / Law and Politics in Africa, Asia and Latin America 45 (2012), 195- 221, (196).

90 Makau Mutua, 'What is TWAIL?', Proceedings of the ASIL Annual Meeting 94 (2000), $31-40,(36)$.

91 Mutua (n. 90), 36.

92 Buphinder Chimni, 'Third World Approaches to International Law: A Manifesto', International Community Law Review 8 (2006), 3-27, (23).

93 Chimni (n. 92), 23. 
and the third world, if these supply chain laws are truly to serve their intended purpose of holding TNCs accountable for violations within their GVCs.

TWAILers are concerned with imbalances in international law and argue that the structural factors promoting inequalities between developed countries and Third World states remain embedded within the international system. ${ }^{94}$ Reflective of these power imbalances that characterise the international legal order, TNCs by and large comply with human rights obligations within their home states' territory while a significant proportion of corporate violations of human rights or corporate complicity in such abuses occurs within the states that host their GVCs, notably Third World states. GVCs have even "been described as "global poverty chains" as regulatory gaps emerge, whether by omission or design, that lead to immiseration of labour and a disregard for human rights and environmental abuses at the precarious end of the supply chain': 95

Given the significant discrepancies between the normative goals and actual effects of domestic supply chain laws vis-à-vis Third World peoples, societies and states, TWAIL therefore proffers an indispensable and critical lens for analysing some of the hidden costs of domestic supply chain laws and their extraterritorial application to Third World states; costs which are more often than not borne by third world peoples, societies; and states. However, it is worth pointing out that, 'while TWAIL has its deconstructive angle, it is also a broad umbrella that embraces constructive and reconstructive efforts': $: 96$ This paper falls within TWAIL's reconstructive tendency, as its objective is not only to critique, but also to propose ways of making domestic supply chain laws significantly more sensitive to the concerns of Third World states and the plight of Third World peoples and societies.

Ultimately, 'what TWAIL analysis (with its dogged insistence on history, continuity, centring the Third World, resisting global hegemony, demanding increased global equality, and unmasking the hand of power in the construction of knowledge) affords one', ${ }^{97}$ in this scrutiny of domestic supply chain laws, is the ability to soberly and critically assess the impact of these laws when enacted by powerful countries in the First World and implemen-

94 Anthony Anghie and Buphinder S. Chimni, 'Third World Approaches to International Law and Individual Responsibility in Internal Conflict' in: Steven R. Ratner and Anne-Marie Slaughter (eds.), The Methods of International Law: Studies in International Legal Policy, NO. 36 (Buffalo: William S. Hein and Co. 2006), 191.

95 Celine Tan, 'The Law of Global Value Chains as Transmission Nodes for Global Inequality' (November 2020), Afronomics Law Blog, available online: <https://www.afronomicslaw.org >.

96 Gathii (n. 5), 39.

97 Okafor (n. 87), 186. 
ted in less powerful countries in the Third World. After all, 'powerful states have used international law and international institutions to create a globalised legal environment which protects and facilitates corporate activity'98 and these fears are rightly extendable to the unilateral adoption of domestic supply chain laws by such powerful states. A TWAIL lens thus makes it possible to examine the problem of corporate human rights impunity and unilateral attempts by national governments to regulate GVCs from the critical and crucial perspective of the very peoples who tend to be most negatively affected by such transnational corporate activities and their attendant regulation, i. e. Third World peoples.

\section{Some Concerns from a TWAIL Perspective}

\section{a) The Inadequacy of Unilateral Domestic Legislation in the Continuing Absence of Binding International Regulation}

\section{The Critique}

In the international legal order there is a profound asymmetry between the rights and obligations of TNCs. 'While they enjoy substantial rights secured through trade and investment agreements, their human rights obligations are less clear and more difficult to enforce.' ${ }^{\prime 9}$ International law has been unwilling and unable to properly regulate transnational corporate behaviour in the context of human rights violations. The lack of progress in the negotiation of a binding treaty is no coincidence, 'rather, the active resistance of certain states in the face of calls by developing states to negotiate a representative treaty is an example of how the Global North manipulates the international system'. ${ }^{100}$ In the absence of such binding international rules domestic supply chain laws have attempted to regulate nationally, and on the basis of international rules and norms, the activities of corporations that operate transnationally.

However, given the power of TNCs in todays globalised world, the expectation that domestic law would be sufficient to impose human rights

98 Simmons (n. 26), 12.

99 Lonel Zamfir, 'Towards a Binding International Treaty on Business and Human Rights' (2018), European Parliament Research Service, available online: <https://www.europarl.europa. $\mathrm{eu} />, 1-12(5)$.

100 Naef Brendan, 'The Responsibility of Home States for Violations of International Obligations by their Corporate Citizens in Fragile States' (2019), PhD Thesis University of British Columbia, available online: <https://open.library.ubc.ca/>, 127. 
related obligations and to hold TNCs accountable is simply unrealistic. ${ }^{101}$ It is thus impossible and impracticable to undertake any meaningful critique of domestic supply chain laws without positioning such critique within the broader question of why international law has failed to (up until now) come up with binding rules to regulate business and human rights. This would be akin to treating only the symptoms but not the underlying disease. While an extensive analysis of the complexities of the regulation (or lack thereof) of business and human rights at the international level is beyond the scope of this paper, it is necessary to illuminate these failures because the structural factors that have contributed to these complexities at the international level do not cease to exist when states unilaterally attempt to regulate transnational corporate behaviour through supply chain laws.

One of the first steps towards binding international regulation was the development of the Draft Norms in the Responsibilities of Transnational Corporations and Other Business Enterprises by the Sub-Commission on Human Rights in 2003. ${ }^{102}$ These Draft Norms were however 'not adopted by the Commission on Human Rights given a large division between developing and developed countries'. ${ }^{103}$ In the wake of the failed Draft Norms the mandate of the Special Representative of the Secretary-General (SRSG) was set up culminating in the adoption of the Guiding Principles on Business and Human Rights in 2010. While laudable, the Guiding Principles do not and cannot adequately address the problem of corporate impunity for human rights and other violations within the context of their GVCs. A binding treaty would probably do more in this regard. This issue was firmly placed on the international law-making agenda when in 2014, the Human Rights Council passed a resolution establishing 'an intergovernmental working group on a legally binding instrument on TNCs and other business enterprises with respect to human rights'. ${ }^{104}$ Interestingly, albeit unsurprisingly, the resolution

'was sponsored by Ecuador and South Africa - both of whom have historical experiences with businesses violating fundamental rights within their states - and garnered 20 votes in favor, 13 abstentions, and 14 votes against it. The voting patterns reflect a split between developed countries and developing countries as

101 Zamfir (n. 99), 7.

102 Working Group on the Working Methods and Activities of Transnational Corporations pursuant to Resolution 2002/8, 'Draft Norms on the Responsibilities of Transnational Corporations and Other Business Enterprises with regard to Human Rights' (2003), available online: $<$ http://hrlibrary.umn.edu/>.

103 David Bilchitz, 'The Necessity for a Business and Human Rights Treaty', Business and Human Rights Journal 1 (2016), 203-227 (205).

104 Human Rights Council (n. 11). 
well as between more established economic powers such as the United States and European Union (which voted against) and emerging economic powers such as China and India (which voted in favor).'105

Several key milestones have occurred since then. In July 2018 the working group published the Zero Draft Treaty on Business and Human Rights. ${ }^{106}$ This was soon thereafter followed by the First Revised Draft Treaty on Business and Human Rights in July of 2019, ${ }^{107}$ and more recently in August 2020 by the release of the Second Revised Draft. ${ }^{108}$ While it is still too early to tell whether there will eventually be a binding international treaty to regulate TNCs, it behooves us to acknowledge that when home states unilaterally enact domestic supply chain laws they run the risk of perpetuating the very challenges that animate Third World states' and peoples' concerns by failing to contextualise these laws within the broader themes of power imbalances and resource asymmetry that have plagued the international front and that have undoubtedly exacerbated the difficulties in coming up with a binding treaty.

Such unilaterally enacted domestic laws 'raise the spectre of vigilante justice"109 and are prima facie 'inherently in conflict with international law understood as a consent-based positivist inspired project'. ${ }^{110}$

\section{The Proposal: Strengthen International Law in the Area of Business and Human Rights}

Despite the uneasy relationship between TWAIL and mainstream international law, this paper strongly argues that the best and most effective way of regulating the GVCs of TNCs is through the use of international rather than national law. Granted, host states that have proven to be unwilling and/or unable to uphold international law are unlikely to have a change of heart in the context of an internationally negotiated business and human rights treaty. Regardless of this fear, international law should nevertheless be given precedence over national attempts at regulation. It may be wishful thinking to

105 Bilchitz (n. 103), 204.

106 Inter-Governmental Working Group, 'Zero Draft of a Legally Binding Instrument to Regulate, in International Human Rights Law, the Activities of Transnational Corporations and Other Business Enterprises' (2018), available online: <https://www.ohchr.org/>.

107 Inter-Governmental Working Group, 'Revised Draft of a Legally Binding Instrument to Regulate, in International Human Rights Law, the Activities of Transnational Corporations and Other Business Enterprises' (2019), available online: <https://www.ohchr.org/>.

108 Inter-Governmental Working Group, 'Second revised Draft of a Legally Binding Instrument to Regulate, in International Human Rights Law, the Activities of Transnational Corporations and Other Business Enterprises' (2020), available online: <https://www.ohchr.org/>.

109 Okowa (n. 1), 687.

110 Okowa (n. 1), 689. 
suggest this, but perhaps a future international business and human rights treaty could even authorise unilateral law making by individual nation states and put in place necessary safeguards to ensure that such domestic lawmaking is normatively defensible and procedurally acceptable.

To reiterate, while the journey towards a binding international treaty on business and human rights is undoubtedly slow, it should not be abandoned. 'Multilateral processes provide the most realistic way of accommodating the diverse interests of States in a pluralist international society." ${ }^{111}$ The higher chances of participation available for Third World states and peoples within the context of the development of a binding treaty at least begins to allow these states and peoples to have a voice in the process. This is in contradistinction to the situation relating to the enactment and implementation of domestic supply chain laws by powerful first world countries with a chequered imperial past. The reality of the matter is that despite the (potentially) good intentions of first world law makers in these instances, 'there remains a justifiable scepticism that those with hegemonic interests cannot be the best custodians of third state interests in the absence of a framework for international oversight'. ${ }^{112}$

\section{b) The Extraterritorial Application of Domestic Supply Chain Laws}

\section{The Critique}

To begin with, by their very nature, most domestic supply chain laws are partly or fully extraterritorial in their design and application. This is potentially problematic 'because the direct regulation of production in other jurisdictions raises difficult questions of sovereignty, legitimacy, and participation.'113 In fact, 'criticism of extraterritoriality in the business and human rights context frequently makes reference to extraterritorial jurisdiction as an infringement of host state sovereignty'. ${ }^{114}$ Thus, 'supply chain regulation exemplifies a distinct model of outsourcing that dilutes the host state's governing authority'. ${ }^{115}$

111 Okowa (n. 1), 688.

112 Okowa (n. 1), 689.

113 Salminen and Rajavuori (n. 21), 610.

114 Rachel Chambers, 'An Evaluation of Two Key Extraterritorial Techniques to Bring Human Rights Standards to Bear on Corporate Misconduct: Jurisdictional Dilemma Raised/ Created by the use of the Extraterritorial Techniques', Utrecht Law Review 14 (2018), 22-39 (26).

115 Sarfaty (n. 9), 421. 
This incursion upon the sovereignty of Third World states raises a red flag from the TWAIL vantage point, especially when the historical context of state sovereignty is taken account, and is something that should not and cannot be downplayed in any realistic study of the regulation of TNCs whether nationally or internationally. As Seck astutely points out, 'any claim that third-world sovereignty will be infringed by first-world home state regulation is suspect to the extent that it denies the on-going history of infringement that dates from the colonial encounter to the neo-colonialism of today's economic order'. ${ }^{116}$ International law and international institutions have wittingly (or unwittingly) contributed to the creation of power imbalances between (typically Global North) home and (Global South) host states. This imbalance is replicated when powerful home states use their national laws to regulate the relationship between rich TNCs and impoverished host states, a structure of legal regulation that is straight out of the European/ Global South colonial encounter. 'The fear being articulated is that the use of extraterritorial techniques may continue - and perhaps further consolidate the historical violation of third world sovereignty.'117

\section{The Proposal: Improved Consultation and Cooperation Between the Home States and Host States and Peoples}

If the above TWAIL concern is insurmountable, then it would appear that domestic attempts to extraterritorially regulate GVCs find themselves between a rock and a hard place. On the one hand in order for the (Global North) home state to regulate or adjudicate extraterritorially, there is necessarily some degree of incursion into the domestic affairs of the host state, and this may be viewed as an impermissible infringement of (the Global South) host state's exclusive jurisdiction and/or as being imperialist/neo-colonialist'. ${ }^{118}$ On the other hand, 'to limit regulation and adjudication to events and actors wholly within the territorial state, may create a regulatory and adjudicatory vacuum where corporate misconduct is transnational, spanning home and host state and/or where the host state is unwilling or unable to regulate or adjudicate over the locally incorporated subsidiary or other affiliate company. ${ }^{\prime 119}$ How should this dilemma be resolved? Is respect for the host state sovereignty more important than holding TNCs liable for human rights and other violations within their GVCs?

116 Sara Seck, 'Unilateral Home State Regulation: Imperialism or Tool for Subaltern Resistance? Osgoode Hall L. J. 46 (2008), 565-603 (582).

117 Chambers (n. 114), 27.

118 Chambers (n. 114), 23.

119 Chambers (n. 114), 23. 
Fortunately, TWAIL does not require that such an impossible choice to be made. TWAILers share 'a historically aware methodology - one that challenges the simplistic visions of an innocent third world and a colonising and dominating first world'. ${ }^{120}$ I would posit that a TWAIL lens allows us to appreciate both the risk to host states' and peoples' sovereignty inherent in the enactment and implementation of extraterritorial domestic supply chain laws, while at the same time acknowledging the necessity of these types of supply chain laws in increasing the accountability of TNCs for human rights abuses within their GVCs. To be clear, I believe that an internationally negotiated binding treaty on business and human rights is the best alternative to deal with the TWAIL concerns articulated in this paper. However, in the absence of exactly this kind of binding international regulation, subsequent sections will propose ways to diminish the concerns associated with domestic supply chain laws.

Perhaps a compromise that will allow us to have our (respecting the host state sovereignty) cake and eat it too (holding TNCs to account for violations within their GVCs) is finding ways to improve consultation and co-operation between home and host states in relation to unilateral measures intended to be taken by one state- the home state - that may have extraterritorial impacts in another state - the host state, consequently reducing the 'democratic deficit of extraterritoriality'. ${ }^{121}$ This could be done 'by legislatures, courts, and regulators commencing a dialogue with their foreign equivalents, "either through institutionalised channels, or though amicus curiae briefs or statements of interest"'122 and would help to avoid or minimise allegations of actual or perceived interference in the domestic affairs of host states where the home states enact laws with an extraterritorial effect. Concurring with the proposals put forward by experts in a session which took place as part of the Ruggie mandate, ${ }^{123}$ Seck argues that consultations should extend to the host states that might be affected by the extraterritorial reach of home state legislation. ${ }^{124}$

Finding ways to involve potential host states as well as the affected Third World people in the law making and implementation processes of supply

120 Gathii (n. 5), 34.

121 Cedric Ryngaert, Jurisdiction in International Law (Oxford: Oxford University Press 2015), 194.

122 Ryngaert (n. 123), 194.

123 UN Special Representative on Business and Human Rights (SRSG), Professor John Ruggie, 'Exploring Extraterritoriality in Business and Human Rights: Summary Note of Expert Meeting' (2010), available online: <https://www.business-humanrights.org/>.

124 Seck (n. 116), 568. 
chain laws that are intended to apply within their territories, recognises the historical disenfranchisement of Third World peoples from decisions on questions that affect their everyday realities. This displays fidelity to TWAIL's call for the inclusion of Third World peoples in the formation of (inter)national law in an attempt to take international legal history seriously particularly in terms of the relations between formerly colonial countries and their colonial overlords'. ${ }^{25}$

Granted, this proposal may be simplistic and perhaps even too challenging to implement, given the reality of asymmetrical power relations as well as conflicting interests between host states and home states and even between the host state government and the potentially affected peoples within its territory. For instance, it is not inconceivable to visualise a situation where a less than democratic host state is willing to sacrifice the protection of human rights and interests of domestic workers within the GVCs of TNCs operating within its territory upon the altar of attracting (more) foreign investment. This calls to mind the case of oil and gas giant, Royal Dutch Shell, and the circumstances surrounding its operation in Nigeria as well as subsequent lawsuit in the Netherlands. ${ }^{126}$

However, this hurdle should not detract from home states' attempts to carve out spaces in both the supply chain law making and implementation process where the voices of potentially affected Third World peoples can be heard and factored into the making of decisions that affect them. Regional organisations, whose membership encompasses numerous host states, could be useful in this regard. Their inclusion as potential stakeholders in the process of supply chain law making and implementation could potentially enhance the legitimacy of the laws made, and in turn diminish the concerns of overreach. It would be disingenuous for TWAIL and TWAILers even while critiquing unilateral home state legislation, to deny the reality that unilateral actions by powerful states can act as a catalyst for significant changes in the normative values of the community of states, which in turn, can produce substantial changes in international law ${ }^{127}$ as well as in host states themselves. Thus, the task is to fashion an acceptable role for such powerful home states that is properly balanced against the interests of Third World host states and peoples.

125 Gathii (n. 5), 40.

126 Esther Hennchen, 'Royal Dutch Shell in Nigeria: Where do Responsibilities End?' Journal of Business Ethics 129 (2015), 1-25 (2-3).

127 Seck (n. 116), 568. 
c) "The (White) Saviour Complex"

\section{The Critique}

TWAIL offers both theoretical and methodological tools for dissecting actions that have a transnational character. ${ }^{128}$ A fundamental concern of TWAIL scholarship is to engage with the question, 'how does a particular rule or legal regime empower or disempower people in the Third World'?129 In seeking to answer this question and building on the above proposal to include third world voices in processes of domestic law making and implementation where the laws have an extraterritorial effect, I further argue that there is a need to avoid the (white) saviour complex.

I craft this idea of the 'white saviour' by borrowing from the 'SavagesVictims-Saviors"'metaphor popularised by TWAILer, Makau Mutua. ${ }^{130} \mathrm{Mu}-$ tua rather provocatively argues that the first dimension of this metaphor, the savage, may be seen to be the state. States become savage when they fail to guarantee human rights, e.g. where a host state fails to guarantee human rights within its territory. In line with this metaphor, I posit that the savage could also be conceptualised as a TNCs which is complicit in human rights violations within its GVC. The second dimension of the metaphor depicts a victim, i. e. the human being whose 'dignity and worth' have been violated by the savage. This could be the labourers or other victims of corporate human rights impunity within the GVCs. Finally, the saviour is seen as the 'good angel who protects, vindicates, civilises, restrains, and safeguards'. ${ }^{131}$ This saviour may be the concerned first world government, the home state, that enacts a domestic supply chain law in this case.

As my site of contestation, I critique this idea of domestic supply chain laws being made by first world governments (the saviours) ostensibly for the benefit of Third World peoples (the victims) but without their input, in order to protect them from harms occasioned by 'the savage' (whoever this may be, whether the host state that fails in its obligation to protect human rights, or the TNC that intentionally or unintentionally fails to respect human rights within its GVCs). There is a need to be cautious about 'perpetuating the image of agency-lacking victims who are rescued by Western saviours operat-

128 Aaron Dhir, 'Shareholder Engagement in the Embedded Business Corporation: Investment Activism, Human Rights and TWAIL Discourse', Comparative Research in Law \& Political Economy, Research Paper No. 12/2009 (2009), 1-22 (13).

129 Anthony Anghie, 'TWAIL: Past and Future', International Community Law Review 10 (2008), 479-481 (480).

130 Makau Mutua, 'Savages, Victims and Saviors: The Metaphor of Human Rights', Harv. Int'l L. J. 42 (2001), 201-245.

131 Mutua (n. 130), 204. 
ing upon the tenants of liberalism. Despite good intentions, there is a real danger of replicating the dominant/submissive binary of the colonial encounter.' 132

\section{The Proposal: Magnifying Third World Voices and Concerns}

As already outlined in the preceding section, Global North law makers that are cognisant of TWAIL critiques ought to take the necessary steps to include the voices of potentially affected Third World peoples in the lawmaking processes of domestic supply chain laws. As Seck points out, 'the legitimacy of home state regulation will thus depend upon the extent to which it gives a voice to host state local communities'. ${ }^{133}$ At a minimum this could include consulting with host states/communities on the design of these domestic supply chain laws. Anything less could be argued to perpetuate and continue the 'civilising mission', a term that is 'employed by numerous academics writing from a TWAIL perspective to "refer to the different methods employed by the West to justify intervention in the affairs of nonwestern societies"'. ${ }^{134}$

Let us, for a moment, turn domestic supply chain laws on their head. In the international and globalised world that we live in with all its attendant hierarchies and power imbalances, would it be possible to have host states, i. e. Third World states (rather than Global North home states) making the supply chain laws that govern the operations of TNCs that have GVCs on their territories in order to compel compliance with human rights and environmental norms? In theory, yes this may be possible. In fact, for example, in 2012 the Democratic Republic of Congo passed a law requiring all mining and mineral trading companies operating in the country to undertake due diligence on all levels of their supply chain according to the OECD Due Diligence Guidance for Responsible Supply Chains. ${ }^{135}$ However, in reality, power imbalances between Third World states and most host states means that there is often regulatory reform aimed at creating an environment more conducive to foreign corporate activity rather than less of it. ${ }^{136}$ While host states compete to attract TNCs 'by offering a legal and economic environment that is as lenient

$132 \operatorname{Dhir}($ n. 128), 14.

133 Seck (n. 116), 568.

134 Dhir (n. 128), 5.

135 (DRC) Circular Note No. 002/CAB.MIN/Mines/01/2011 of 6.9.2011 relating to the Mandatory Implementation of the Guidelines and Recommendations of the OECD Due Diligence Guide and UN Resolution 1952 in the Congolese Mining Sector; Global Witness, 'Congo Government Enforces Law to Curb Conflict Mineral Trade' (2012), available online: $<$ https://www.globalwitness.org/>.

136 Christine Chinkin, 'The State That Acts Alone: Bully, Good Samaritan or Iconoclast?' EJIL 11 (2000), 31-41 (38). 
as possible, home states are often interested in promoting the foreign investments of their corporate nationals and in benefiting from their economic benefits abroad'. ${ }^{137}$ In acknowledging this reality, it is therefore necessary to do more to include third world communities in the law-making processes of laws aimed at affecting their quotidian realities. Subaltern perspectives and experiences, such as those of labourers and communities affected by the operations of GVCs, should be central to the development of binding international rules regulating corporate impunity and by extension, domestic supply chain laws that have an extra territorial effect.

\section{d) The Nature of the Companies' Duties Under Domestic Supply Chain Laws}

\section{The Critique}

As already elaborated upon in preceding sections of this paper, 'Given the shortcomings of international law, domestic legislation is emerging as an alternative method for regulating the extraterritorial human rights abuses of corporations'. ${ }^{138}$ Within this turn to domestic law there is a wide variety of duties that may comprise obligations for the covered companies under the different domestic supply chain laws. These may range from voluntary to mandatory requirements, and from mere disclosures as is the case with the California Transparency in Supply Chains Act (supply chain disclosure regimes) to more demanding expectations as in the French Corporate Duty of Vigilance Law as well as German Supply Chain Act (supply chain due diligence regimes).

In most cases, supply chain disclosure regimes that require only disclosure without more, are unlikely to have the intended effect of holding transnational corporate actors liable for human rights violations within their GVCs. These disclosure regimes do not impose an affirmative obligation on TNCs to rid their GVCs of human rights abuses; rather, they only impose a requirement to disclose any supply chain due diligence that they have undertaken. On the surface at least, it is thus feasible that a company is able to comply with the disclosure requirements of the domestic supply chain law in question without significantly altering its human rights track record.

When compared to the requirements imposed by supply chain disclosure regimes the expectations under a supply chain due diligence regime are likely to be more demanding. For instance, like its French counterpart, (and unlike

137 Berkes (n. 24), 307.

138 Chilton and Sarfaty (n. 42), 3. 
the California Act discussed above) the German Act goes a little further beyond mere mandatory disclosures. It requires a number of obligations from the covered companies: a risk analysis, preventative measures where feasible and remedial measures where appropriate. Why do supply chain laws frame the obligations in this way? Why not instead demand that companies actually refrain from committing human rights violations? Are due diligence efforts reliable proxies for human rights outcomes or are 'they incapable of shaping company behaviour to ensure that companies respect the rights of people'?139 This is part of a broader normative problem that goes back to how international law has structured corporate liability for human rights violations. As Penelope Simmons notes, 'corporate human rights impunity is deeply embedded in the international legal system'. ${ }^{140}$ Since domestic supply chain laws are enacted with due regard to prevailing international law norms in this area, any normative inadequacies in the latter are likely to be replicated in the former. Thus, since international law does not impose binding obligations on corporate actors in the area of human rights, this birth defect is likely to be passed on to the national law, and domestic supply chain laws are therefore unlikely to overreach and impose direct human rights obligations on corporate actors. In fact, Simmons argues that during the process leading up to the adoption of the Guiding Principles for Business and Human Rights, the Special Representative to the Secretary General - Ruggie, identified symptoms of this reality during his tenure but did not examine the deep structural aspects of this problem [...] such an examination by the SRSG would have revealed the crucial need for binding international human rights obligations for business entities in any adequate strategy aimed at addressing corporate impunity'. ${ }^{141}$

Additionally, the obligations imposed on the covered TNCs have been argued to be too 'business-centric' in some cases giving businesses too much leeway in 'determining what tools to use, how to implement such tools and whether the depth and breadth of such tools is compatible with the potential and real human rights impacts'. ${ }^{142}$ This kind of 'soft' regulation is problematic because it gives too much power to businesses thus failing to properly hold them to account whenever violations occur.

139 Mark B. Taylor, 'Human Rights Due Diligence in Theory and in Practice' in: Surya Deva and David Birchall (eds.), Research Handbook on Human Rights and Business (Cheltenham: Edward Elgar 2020), 88-107 (104).

140 Simmons (n. 26), 11.

141 Simmons (n. 26), 12.

142 Daniella Chimisso dos Santos and Sara Seck, 'Human Rights Due Diligence and the Extractive Industries' in: Surya Deva and David Birchall (eds.), Research Handbook on Human Rights and Business (Cheltenham: Edward Elgar 2020), 151-174 (167). 


\section{The Proposal: Impose Clear and 'Hard' Binding Obligations on TNCs}

In his analysis of colonialism and international law, Anthony Anghie assesses how international law has been used, from colonial times to the present, as a tool of subjugation of the peoples of the Third World. ${ }^{143}$ 'Unsurprisingly, the economic interests of European and other Northern states (and their corporate actors) played a central role in this history', ${ }^{144}$ with corporations being part and parcel of the toolkit of the colonialists in their quest to protect and promote their economic interests. Against this historical backdrop of the use of corporations in the subjugation of Third World peoples, it becomes necessary for TWAILers to not only point out the current gaps in regulating transnational corporate behaviour both nationally and internationally, but also to recommend ways in which binding obligations aimed at addressing corporate impunity can be incrementally developed.

TWAIL would therefore call for the reformation of international law in this area because 'the lack of direct international oversight has an important impact on how the domestic sphere deals with these actors'. ${ }^{145}$ So long as international law continues to impose only indirect obligations on TNCs through the use of tools such as the Guiding Principles, it is likely that domestic supply chain laws will follow suit and only hold transnational corporate actors to account within the framework of supply chain due diligence regimes. For this to change at the national level, international law itself has to change as well moving from 'soft' or 'voluntary' forms of regulation of corporate actors to more binding and 'hard' forms. As Ruggie himself has noted, 'it may be desirable in some circumstances for corporations to become direct bearers of international human rights obligations, especially where host governments cannot or will not enforce their obligations and where the classical international human rights regime, therefore, cannot possibly be expected to function as intended'. ${ }^{146}$ Hence, if international law evolves to allow for the creation of international corporate human rights obligations together with effective enforcement mechanisms it would be possible that 'human rights obligations for corporate actors could begin to shift the balance of power between transnational corporate actors on the one hand, and Third World host states and victims of corporate human rights

143 Anthony Anghie, Imperialism, Sovereignty and the Making of International Law, (Cambridge; Cambridge University Press, 2005), 211.

144 Simmons (n. 26), 20.

145 Simmons (n. 26), 31.

146 UNESCOR, 'Interim Report of the Special Representative of the Secretary-General [SRSG] on the Issue of Human Rights and Transnational Corporations and Other Business Enterprises' (2006), UN Doc E/CN 4/2006/97, 65. 
abuses, on the other'. ${ }^{147}$ This will in turn alter the nature and efficacy of the obligations of TNCs to ensure human rights within their GVCs as envisioned under domestic supply chain laws.

\section{e) The 'Burden' of the Burden of Proof}

\section{The Critique}

Like many other supply chain laws the German Act does not give the victims of violations the right to obtain redress through a complaint mechanism. However is anticipated that in future the victims 'can authorise NonGovernmental Organisations (NGOs) and trade unions to raise such claims using the already existing causes of action - on their behalf directly before German courts. ${ }^{148}$ This does not go enough to reduce the burden of proof borne in such circumstances and which would have to be met in order for affected parties to receive suitable redress.

Where a domestic supply chain law places a burden of proof on the often extremely vulnerable victim of this kind of violation, to prove damage caused within the GVC of a TNC, before they can be able to secure compensation in the home state, this law fails the TWAIL litmus test. In light of the very real power differences that exist between the potential victim(s) (probably an individual or a group of individuals in the Third World) and a powerful TNC based in a far-off home state, the burden of proof on such victims is likely to be a burden too heavy to bear. This may be attributed to the twin perils of the 'victims' very limited financial resources to initiate litigation'149 and actually prove their case, as well as the difficulty in accessing 'assets outside the host state's jurisdiction'.

\section{The Proposal: Include Reverse Onus Provisions in Domestic Supply Chain Lares}

I posit that in order to enhance their ability to allow victims of corporate impunity to actually access suitable redress in reality and not just on paper, domestic supply chain laws should include a reverse burden of proof provision that operates in favour of individuals or groups of individuals who intend to bring actions against powerful TNCs seeking compensation for violations that occurred within their GVCs. This would go a long way towards beginning to level the playing field between the victims and the

147 Simmons (n. 26), 41.

148 Initiative Lieferkettengesetz (n. 43), 3.

149 Berkes (n. 24), 317. 
transgressors in these corporate impunity cases. ${ }^{150}$ This 'reversal of the burden of proof in favour of the victim is necessary given that the relevant information concerning the operations of the company and the organisation of its relations with its subsidiaries or business partners resides with the company, and is generally not easily accessible to the victim'. ${ }^{151}$

It is interesting, but unsurprising, to note that when the French Corporate Duty of Vigilance law was being drafted, 'the bill was significantly weakened during the parliamentary process following opposition from business. A provision to reverse the burden of proof in international corporate accountability cases, requiring the company concerned to prove that it was not in control of the activities of its subsidiaries and subcontractors was removed from the final text." ${ }^{152}$ A similar fate befell the comparative provision in the Swiss Responsible Business Initiative which proposed a partial reversal of the burden of proof in favour of potential victims by providing that 'when a controlled company causes harm, the controlling company is liable unless it can prove that it took all due care to avoid the harm or loss, or that the damage would have occurred even if all due care had been taken. It is up to the company to prove that it took all due care (partial reversal of the burden of proof).' ${ }^{153}$ The Responsible Business Initiative was narrowly rejected in November 2020.154 Despite the failure of both the French and the Swiss reversal of burden of proof provisions, it is clear that a reversal of the burden of proof is a possibility that should not be lightly taken off the table.

\section{f) The Paradox of Regulated Entities Becoming Regulators Themselves}

\section{The Critique}

In order to develop the normative content of a corporate responsibility for human rights under domestic supply chain laws, these laws convert the regulated TNC itself into a regulator, responsible for regulating the myriad

150 Dr. Axel Marx and others, 'Access to legal remedies for victims of corporate human rights abuses in third world countries' (2019), available online: <https://www.europarl.europa. $\mathrm{eu} />$.

151 International Trade Union Confederation, 'Towards Mandatory Due Diligence in Global Supply Chains', available online: <https://www.ituc-csi.org/>.

152 CORE, 'Mandatory Human Rights Due Diligence: Developments in Europe' (2016), available online: <https://corporate-responsibility.org/>.

$153 \operatorname{Dhir}$ (n. 128), 14.

154 Business and Human Rights Centre, 'Switzerland: Responsible Business Initiative Rejected at Ballot Box Despite Gaining 50.7 \% of Popular Vote' (2020), available online: <https:// www.business-humanrights.org/>. 
suppliers in subsequent levels of its GVC. Consequently, 'multinational companies are more than just regulated entities; they now also serve as regulators themselves, imposing standards on their third-party suppliers in other countries'. ${ }^{155}$ But, and this is a big BUT, do we want to give this kind of power (or obligation) to TNCs? Do these transnational corporations have the necessary incentives to ensure compliance by the various firms within their multi-tiered supply chains? 'While outsourcing regulation to companies is a means by which states can indirectly regulate firms in other countries, this practice raises accountability concerns when private actors are performing functions that are fundamentally public.' ${ }^{\prime 56}$ In addition, since GVCs frequently include multiple layers of suppliers it is likely that the TNC in question will 'often rely on first-tier suppliers to identify and audit those in the second-tier, who in turn identify and audit the next tier and so on'. ${ }^{157}$ Thus, the obligations placed on companies by domestic supply chain laws are performed not only by the company itself, but by the company in conjunction with third party suppliers in its GVC. As a result, comprehensive monitoring is unlikely to occur because even though companies may be able to easily locate the first-tier suppliers, those suppliers in the lower tiers may not be immediately visible.

Human rights violations frequently occur within GVCs and the victims rarely receive suitable redress primarily because the host countries have weak legal institutions and the home states encounter difficulty in extraterritorially regulating third party suppliers. Abuses may occur at any level of a supply chain, from the first tier of direct suppliers, to layers of subcontractors and even to the firms providing raw material inputs. This chain of outsourcing and accompanying domestic supply chain laws fail to stipulate how far down the supply chain due diligence should be carried out or even how much due diligence is enough due diligence, is a grave concern from the TWAIL point of view. Because the companies themselves are ill equipped (and lack incentive) to monitor and enforce compliance by third parties, they may end up further outsourcing these roles to other private parties such as consulting firms or certification firms who then audit the tiers of suppliers in the value chain.

Where the home state implements domestic supply chain laws it directly regulates the affected TNC and indirectly regulates the other firms in the TNC's GVC. As a result, companies listed in the home state are responsible for implementing and enforcing regulatory standards on firms abroad (in the

155 Sarfaty (n. 9), 421.
156 Sarfaty (n. 9), 422.
157 Sarfaty (n. 9), 430. 
host state), on behalf of the home state. In these instances, the host state's companies must comply with the regulations not because they are legally obliged to do so by a democratically elected parliament in the host state, but rather because the powerful TNC is capable of coercing compliance with the ever-looming sceptre of cessation of business activities where compliance is not present. In this regard a counter argument could be raised to the effect that many host states do not have a democratically elected parliament and as such any supply chain laws passed by such a parliament also lacks legitimacy. While this may be a valid assessment, the lack of a democratically elected host government does not justify indirect regulation in a host state through the TNC. Two wrongs cannot make a right in this case.

A TWAILer would argue that this kind of regulatory role is not a role that TNCs can (or even want to) do effectively. This is further compounded by the fact that these regulatory structures dilute the host state's authority and weakens accountability of firms in the GVCs by creating a spiderweb of obligations which these firms in the host state's territory are expected to comply with. 'The accountability costs are particularly prevalent in supply chain regulation, which becomes further removed from the state as it gets outsourced first to companies and then to other suppliers and private consultants, thus creating second-order regulation, third-order regulation, and so on. ${ }^{\prime 158}$ As responsibility is redistributed across a network of actors there is limited accountability which ironically makes it difficult to hold TNCs liable for violations - thus defeating the purpose of these supply chain laws.

\section{The Proposal: Shift the Bulk of Regulatory Obligations from the GVC to the State}

Because of the multiple levels involved when suppliers in the GVCs are regulating the tiers below them, the home state is likely to be several layers removed from the regulatory process. When private parties are responsible for implementing the regulations without direct governmental oversight accountability deficits are likely to arise. This has implications for how effectively the domestic supply chain laws can be implemented in order to achieve their purpose. There is therefore a need for the home states to become more involved in efforts to promote transparency in the GVCs. This could be done by providing guidance to companies and more technical support necessary to help them in the implementation of supply chain laws. The enactment of the laws and their implementation is just the first of many roles that the home states should play in order to enhance the accountability of TNCs for activities within their GVCs. The state agencies responsible for the

158 Sarfaty (n. 9), 436. 
implementation of these domestic supply chain laws should offer technical and financial assistance to companies to facilitate the mapping of their GVCs in order to enhance the quality of risk assessment and preventive measures deployed.

\section{Some Final Thoughts}

As already articulated by numerous TWAILers and outlined in greater detail in part III above, international laws and institutions have historically coalesced to erode the independence and interests of Third World countries in favour of transnational capital and powerful states. This paper has sought to show that this critique can be extended to the reliance upon domestic supply chain laws by powerful home states to the detriment of Third World peoples and host states.

In making a case for the regulation of GVCs to be done at the international rather than at the national level by individual states, this paper acknowledges that 'contemporary international law offers a protective shield, however fragile, to the less powerful states in the international system' 159 and that 'the international legal process can be used to bring a modicum of welfare to long suffering peoples of the third world'. ${ }^{160}$ However, so long as international law making in the area of business and human rights continues to move at a snail's pace and domestic supply chain laws seek to fill the vacuum caused by a lack of binding international rules regulating the operations of TNCs, it is necessary to address the TWAIL concerns raised by the enactment and implementation of these unilaterally passed domestic laws.

When countries in the First World make domestic supply chain laws that extraterritorially affect Third World peoples and states, a TWAIL lens allows critical legal scholars to question this state of affairs in light of historically asymmetrical power relationships sanctioned by international law to the detriment of the Third World. Thus far, the 'dialogue about home state obligations to regulate and adjudicate transnational corporate environmental harms has been confined to First World states discussing the rights of Third World peoples. There is a need to open that conversation to the states of the Third World [...] at the very least when transnational corporate actors call a developing state "home".'161

159 Chimni (n. 92), 26.

160 Chimni (n. 92), 26.

161 Sara Seck, 'Transnational Business and Environmental Harm: A TWAIL Analysis of Home State Obligations', Trade, Law and Development 3 (2011), 164-202 (201). 
Even when First World law makers have good intentions while enacting domestic supply chain laws these good intentions should not be blind to the fact that laws (whether international or national) that subjugate the Third World have for far too long been 'made in the First World'. These laws 'exemplify hegemony at work and carry with them a real risk of mainstreaming alternative processes of law-making that works in the interests of powerful states at the expense of multilaterally agreed initiatives'. ${ }^{162}$ The nuanced analysis proposed by this paper aims to illuminate the very real concerns that arise when powerful home states unilaterally pass laws aimed at regulating the GVCs of TNCs operating in less powerful host states. On paper, these attempts to rein in rogue TNCs and minimise violations within their GVCs are more than laudable. However, the reality of relations between and within home states and host states paints a rather complex picture.

As TWAIL seeks the reformation of international law to allow it to be more responsive to the needs and concerns of the Third World (for instance, by coming up with a binding treaty on business and human rights), these calls for reform can and should be extended to domestic supply chain laws as well, where domestic laws made in First World states apply extraterritorially to Third World states and peoples through the GVCs of TNCs. In this way it will be possible for such domestic supply chain laws to 'be informed by the counter-hegemonic project of reading subaltern resistance into international law, rather than [to operate] as an illegitimate if not imperialistic exercise of unilateral jurisdiction'. ${ }^{163}$ After all, the twin ideals of resistance and reform lie at the very core of the TWAIL pursuit. TWAILers must (continue to) resist all aspects of (inter) national law that contribute to the subjugation of Third World people's and States, and ceaselessly clamour for the reformation of both laws and institutions that help to maintain this status quo.

162 Okowa (n. 1), 716.

163 Seck (n. 116), 603. 